\title{
Evaluating Optimum Strength of Geopolymer Concrete using Quarry Rock Dust with Inclusion of Natural and Hybrid Fibers Under Ambient Curing
}

\author{
S.Kavipriya, S.Gowtham, S.Kannan
}

\begin{abstract}
Conventionally used cement - a primary binder also a necessitate element in producing concrete rates first in the construction industry. Production of conventional cement requires a greater skill and is energy intensive. The usage of waste materials in the production of concrete and reduction in cement content was only the possible alternative in the past decade. Associated risks with the production of Ordinary Portland Cement are well known. A greener aided with a natural friendly claim can be made only with the usage of the waste materials and reduction in evolving respiration gas to the atmosphere. Almost all works are carried out using source material fly ash, with fine aggregate and coarse aggregate. Concrete plays a vital role in the construction industry and on the other hand, river sand; one of the essential material has become very expensive which is a scarce material. Depletion of sand is a hectic issue due to increased usage of sand in construction. No other replacement materials such as quarry rock dust is not concentrated in casting geopolymer specimens. Even though in some research papers the replacement materials are added only in partial replacement without aiming on $100 \%$ replacement. Many researches mainly focus towards test results of GPC specimens using steel fibers, glass fibers. But the study related to natural fibers and hybrid fibers are found scarce. The main part of this work aimed at characterizing the engineering strength properties of geopolymer concrete by $100 \%$ replacement of fine aggregate with quarry rock dust. Hence, combination of flyash and quarry rock dust in GPC have been considered for evaluating the mechanical properties of geopolymer concrete. Also, investigation focuses on incorporation of three different fibers namely polypropylene fibers(PF), coir fibers(CF) and hybrid fibers $(\mathrm{HF})$ in different percentage of proportions such as $0.5 \%, 1 \%$, and $1.5 \%$ to determine the maximum strength properties of GPC.

Keywords : CA-Coarse Aggregate, CF-Coir Fibers, FA-Fly Ash, GPC- Geo Polymer Concrete, HF-Hybrid Fibers, PF-Polypropylene Fibers, QRD - Quarry Rock Dust.
\end{abstract}

\section{INTRODUCTION}

The Polymerization process involves chemical reactions under alkali conditions with $\mathrm{Si}$ and $\mathrm{Al}$ minerals, which results in the formation of three dimensional polymeric chain and ring structure consisting of Si-O-Al-O bonds.

Revised Manuscript Received on July 10, 2020

* Correspondence Author

Dr.S.Kavipriya*, Associate Professor and HOD, Department of Civil Engineering, Kongunadu College of Engineering and Technology, Thottiam, Tamil Nadu, India. E-mail: kavipriyacivil2001@gmail.com

S.Gowtham, Assistant Professor, Department of Civil Engineering, Kongunadu College of Engineering and Technology, Thottiam, Tamil Nadu, India. E-mail: gowtham.vic16@gmail.com

S.Kannan, Assistant Professor, Department of Civil Engineering, Kongunadu College of Engineering and Technology, Thottiam, Tamil Nadu, India. E-mail: kannanprb@gmail.com

(c) The Authors. Published by Blue Eyes Intelligence Engineering and Sciences Publication (BEIESP). This is an open access article under the CC BY-NC-ND license (http://creativecommons.org/licenses/by-nc-nd/4.0/)
[1] Compared to Portland Cement, manufacturing Geopolymer Cement requires a lesser amount of calcium based raw materials, this results in the reduction of the carbon dioxide percentageat $80-90 \%$ [2]. The polymerization process involves fast chemical reaction under alkaline conditions on silicon- aluminium minerals that results in Polymeric chain and ring structure. The ultimate structure of the geopolymer depends largely on the ratio of Si to Al.[3].The value lies between (2 and 3.5).

The characteristic exhibition of geopolymer depends mainly on two factors a) selection of source material b) processing surrounding with conditions. Generally Source materials are selected which are rich in Silicon (Si) and Aluminium (Al) contents which forms the back bone of the Geopolymer Structure. Materials such as kaolinite, clays etc., are available in natural form; flyash, silica fume, blast furnace slag, rice-husk ash, red mud etc., are obtained as byproduct form[4]. Material availability, Cost, Method of application, demand of the users are also included as a part of the selection criterion. In the present study prime material used as the source material is fly-ash (ASTMC618) which fully replaces cement. Also the filler materials are also used for replacing sand. For instance, quarry rock dust replaces sand. Reduction in environmental pollution, effective usage of waste management, the economic factor and quality of concrete are the aspects considering which the replacement materials are chosen. Solution of $\mathrm{NaOH}$ with $\mathrm{Na}_{2} \mathrm{SiO}_{3}$ is used as the activator solution [5]. Fibres are added in the

Geopolymer concrete specimens to stimulate the properties in a better mode.

\section{MATERIAL PROPERTIES}

Flyash : Class F flyash conforming to IS:3812-2003 obtained from Mettur thermal power station of Tamil Nadu from southern part of India with specific gravity 3.16 was used in the casting of the specimens. For all the combinations of GPC mixes flyash was used as source material.[6]

Quarry Rock Dust: QRD, a byproduct of crushing process can be defined as residue, tailing or other non-voluble waste material after the extraction and processing of rocks to form fine particles less than $4.75 \mathrm{~mm}$ excellently suits as one of the substitute material for the natural river sand. [7].QRD with specific gravity 2.64,fineness modulus 2.86 and bulking of sand $22 \%$ was used as filler material.

Coarse aggregate: Crushed granite coarse aggregates of $20 \mathrm{~mm}$ maximum size having a fineness modulus of 7.3 and specific gravity of 2.75 were used.

\section{Published By:}

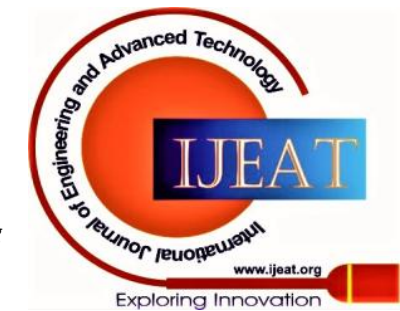


Bulk Density of the coarse aggregate used were 1527 $\mathrm{kg} / \mathrm{m}^{3}$.

Sodium hydroxide: A sodium hydroxide solid in the form of flakes with $97 \%$ purity, purchased from Jayalakshmi Traders, Trichy, was used in the preparation of alkaline activator.

Sodium silicate: Sodium silicate in the form of solution supplied by Jayalakshmi Traders, Trichy, was used in the preparation of alkaline activator. The chemical composition of Sodium silicate solution supplied by the manufacturer is as follows: $14.7 \%$ of $\mathrm{Na}_{2} \mathrm{O}, 29.4 \%$ of $\mathrm{SiO}_{2}$ and $55.9 \%$ of water by mass.

Polypropylene Fibers: Polypropylene fibers are used in the construction industry as a secondary reinforcement to arrest cracks.[8].And to increase resistance to impact and abrasion and also to improvise the quality of construction and the life span of the concrete.[9].The properties are shown in table.I.

Table-I: Properties of Polypropylene Fibers

\begin{tabular}{|l|l|}
\hline Properties & Values \\
\hline Standard Compliance & ASTMC-1116 \\
\hline Shape & Monofilament \\
\hline Standard Length & $12 \mathrm{~mm}$ \\
\hline Specific Gravity & 0.91 \\
\hline Melting Point & $162^{\circ} \mathrm{C}$ and above \\
\hline Absorption & Nil \\
\hline Alkali Resistance & $99 \%$ Strength retained \\
\hline Tensile Strength & $3500-7700 \mathrm{~kg} / \mathrm{m}^{3}$ \\
\hline Young's Modulus & $35 \times 10^{3} \mathrm{~kg} / \mathrm{cm}^{2}$ \\
\hline Diameter & 18 micron,nominal \\
\hline
\end{tabular}

\section{Coir Fibers}

\begin{tabular}{|c|c|c|c|}
\hline \multirow{2}{*}{ 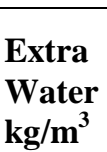 } & \multicolumn{3}{|c|}{ PolypropyleneFiber $\left(\mathrm{kg} / \mathrm{m}^{3}\right)$} \\
\hline & $0.5 \%$ & $1.0 \%$ & $1.5 \%$ \\
\hline 27.50 & 0.0107 & 0.0214 & 0.0322 \\
\hline
\end{tabular}

Coir fibers are one of the organic fibers. In this research work coir fiber of $1.4 \mathrm{~g} / \mathrm{cc}$ were added.

\section{Hybrid Fibers}

Addition of coir fibres and polypropylene fibres result in the formation of hybrid fibres.[12].

\section{MIX DESIGN}

A. Preparation of Alkaline Activator Solution

A molar solution of sodium hydroxide implies concentration in terms of moles/litre. One molar (IM) solution means one mole of a substance per litre of solution. A mole means gram molecular weight or molecular weight of a substance, in grams; hence the molecular weight of a chemical is also its molecular weight.[10]. The molecule of $\mathrm{NaOH}$ consists of one atom each of sodium $(\mathrm{Na})$, Oxygen $(\mathrm{O})$ and hydrogen $(\mathrm{H})$. Their respective atomic weights are Na-23, $\mathrm{O}-16, \mathrm{H}-1$.So the molecular weight is $23+16+1=40$. Thus 40 grams of $\mathrm{NaOH}$ equals One mole of $\mathrm{NaOH} .10 \mathrm{M}$ solution of $\mathrm{NaOH}$ contains 400 grams of $\mathrm{NaOH}$. Accordingly, a $16 \mathrm{M}$ solution of $\mathrm{NaOH}$ was prepared.

The $\mathrm{NaOH}$ and $\mathrm{Na} 2 \mathrm{SiO} 3$ were shown in fig 1 . and 2.To avoid the effects of unknown contaminants in laboratory tap water, distilled water was used for preparing the activator solution. The solution was prepared one day prior to its use in the casting of specimen to achieve the desired alkalinity. The ratio of sodium silicate to sodium hydroxide was considered as 2.5 based on the study of previous literature.[11].Mix design parameters have been tabulated in table. II. The mix proportion of GPC is given in table.III. Mix proportion of polypropylene fibers are shown in table.IV. Mix proportion of coir is tabulated in table.V and hybrid fibers are shown in table.VI.

\begin{tabular}{|c|c|c|}
\hline i) & $\begin{array}{c}\text { Ratio of Source material } \\
\text { to alkaline } \\
\text { activator solution }\end{array}$ & 0.47 \\
\hline ii) & $\begin{array}{l}\text { Ratio of sodium } \\
\text { hydroxide to } \\
\text { sodium silicate }\end{array}$ & 2.5 \\
\hline iii) & Concentration of $\mathrm{NaOH}$ & $16 \mathrm{M}$ \\
\hline iv) & Ambient Curing & $27^{\circ} \mathrm{C}$ \\
\hline v) & $\begin{array}{c}\text { Specific gravity of } \\
\mathrm{Na}_{2} \mathrm{SiO}_{3} \\
\end{array}$ & 1.6 \\
\hline vi) & Molarity of $\mathrm{NaOH}$ & $16 \mathrm{M}$ \\
\hline vii) & $\mathrm{NaOH}: \mathrm{Na}_{2} \mathrm{SiO}_{3}$ & $01: 02.5$ \\
\hline viii) & $\begin{array}{l}\text { Alkaline liquid to flyash } \\
\text { ratio }\end{array}$ & 0.61 \\
\hline
\end{tabular}

Table-III: Mix Proportion of GPC

\begin{tabular}{|l|c|l|l|l|l|}
\hline \multirow{2}{*}{ Mix } & $\begin{array}{l}\text { Flyash } \\
\mathbf{k g} / \mathbf{m}^{3}\end{array}$ & $\begin{array}{l}\text { QRD } \\
\mathbf{k g} / \mathbf{m}^{3}\end{array}$ & $\begin{array}{l}\mathbf{C A} \\
\mathbf{k g} / \mathbf{m}^{3}\end{array}$ & $\begin{array}{l}\mathbf{N a O H} \\
\mathbf{k g} / \mathbf{m}^{3}\end{array}$ & $\begin{array}{l}\mathbf{N a}_{2} S \mathbf{O} \\
\mathbf{O}_{3}\end{array}$ \\
\hline GPC-2 & 550 & 586.3 & 1033.2 & 42.17 & 239.6 \\
\hline
\end{tabular}

Table-IV: Mix Proportion of Polypropylene Fibers

Table-V: Mix Proportion of Coir Fibers

\begin{tabular}{|l|l|l|}
\hline \multicolumn{3}{|c|}{ Coir Fiber $\left(\mathrm{kg} / \mathrm{m}^{\mathbf{3}}\right)$} \\
\hline $\mathbf{0 . 5 \%}$ & $\mathbf{1 . 0 \%}$ & $\mathbf{1 . 5 \%}$ \\
\hline 0.0165 & 0.0330 & 0.0495 \\
\hline & & \\
\hline
\end{tabular}

Published By:

Blue Eyes Intelligence Engineering

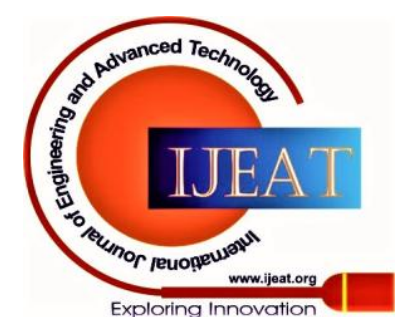


Table-VI: Mix Proportion of Hybrid Fibers

\begin{tabular}{|l|l|l|}
\hline \multicolumn{3}{|c|}{ Hybrid Fiber $\left.\mathbf{( k g / \mathbf { m } ^ { 3 }}\right)$} \\
\hline & & \\
$0.25 \% \mathrm{PF}+0.25 \% \mathrm{CF}$ & $0.5 \% \mathrm{PF}+0.5 \% \mathrm{CF}$ & $\begin{array}{l}0.75 \% \mathrm{PF}+ \\
0.75 \% \mathrm{CF}\end{array}$ \\
\hline & & $0.0161+$ \\
$0.0053+0.0082$ & $0.0107+0.0165$ & 0.0247 \\
\hline
\end{tabular}

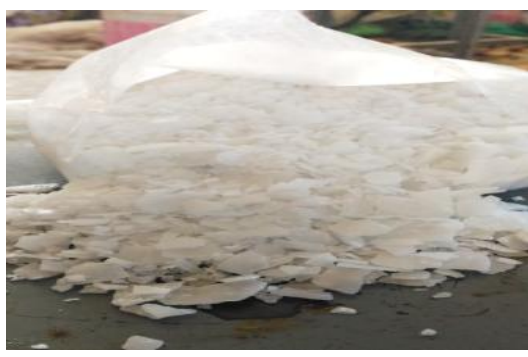

Fig.1. NaOH- Flake form

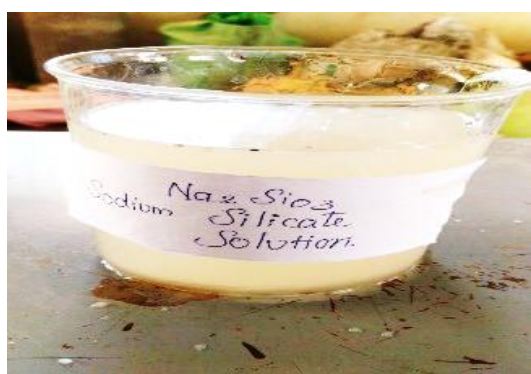

Fig.2. Na2SiO3- Aqueous form

IV. RESULTS AND DISCUSSION

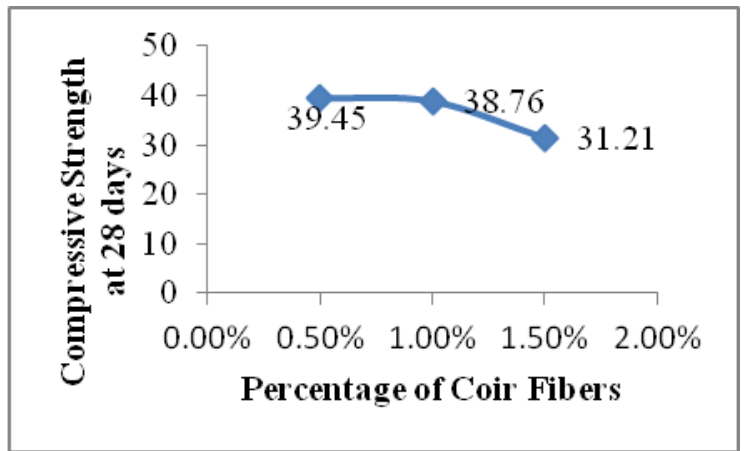

Fig.3.Compressive Strength of Polypropylene Fibers

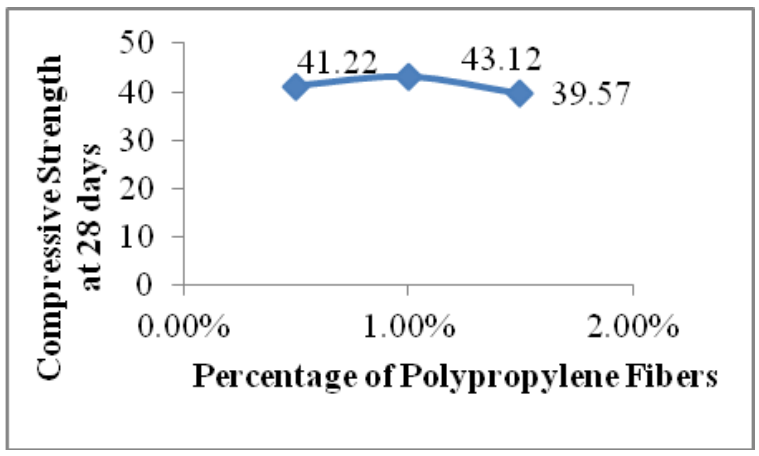

Fig.4.Compressive Strength of Coir Fibers

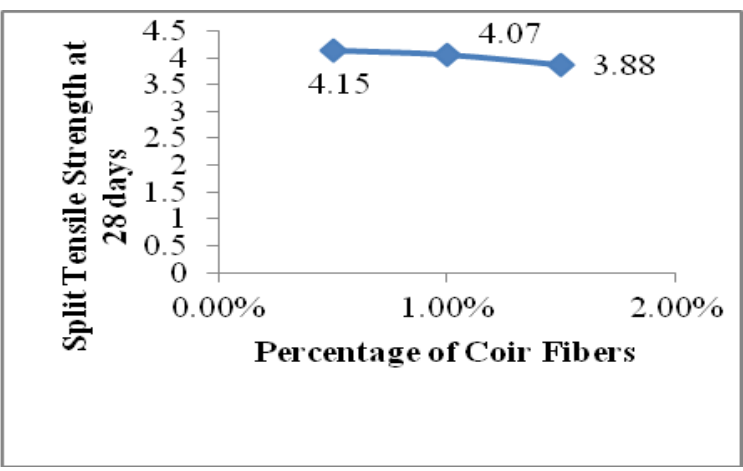

Fig.5.Compressive Strength of Hybrid Fibers

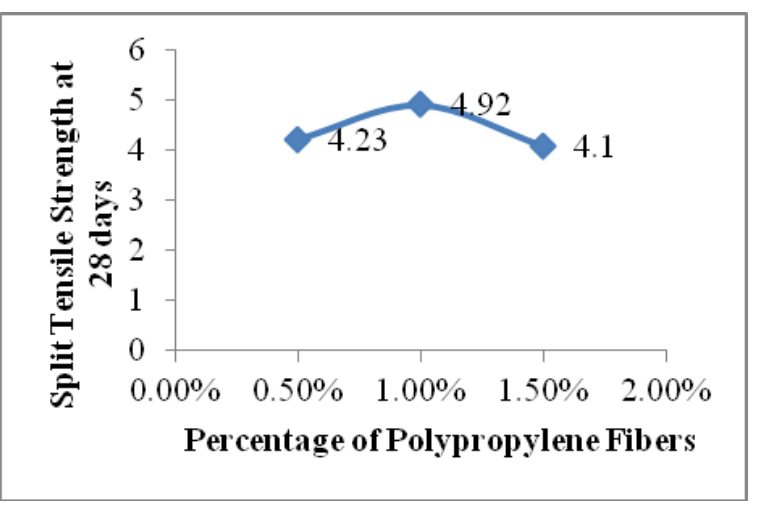

Fig.6.Split Tensile Strength of Polypropylene

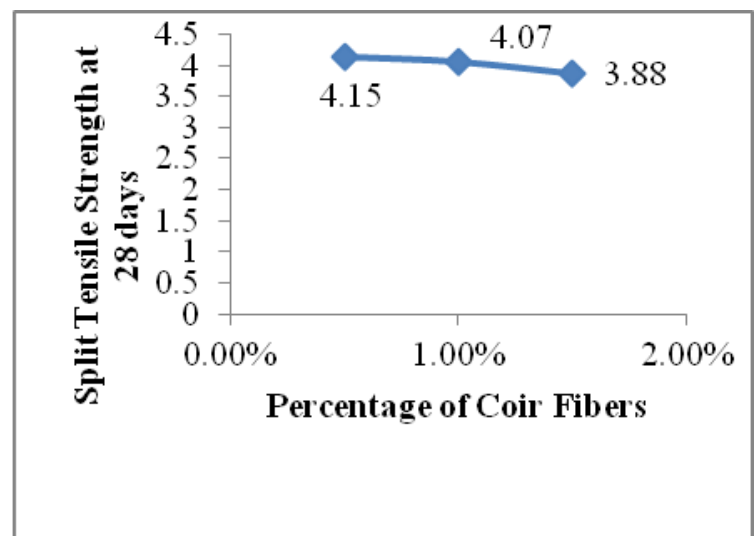

Fig.7.Split Tensile Strength of Coir Fibers

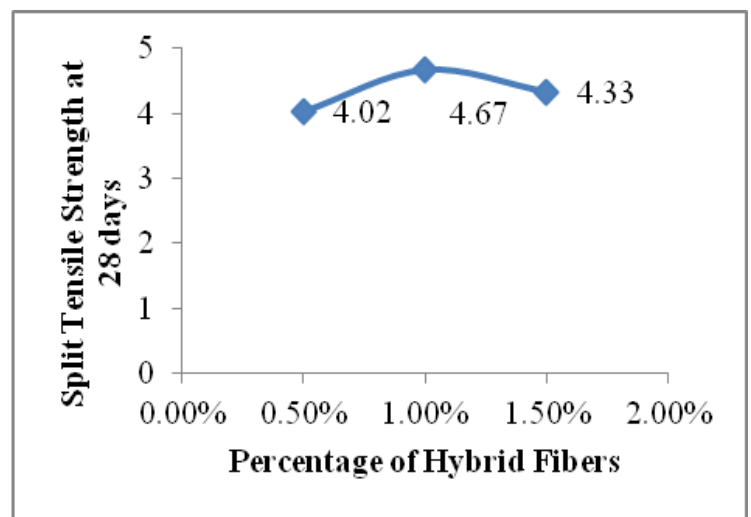

Fig.8.Split Tensile Strength of Hybrid Fiber

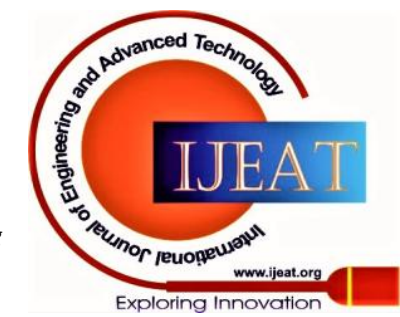




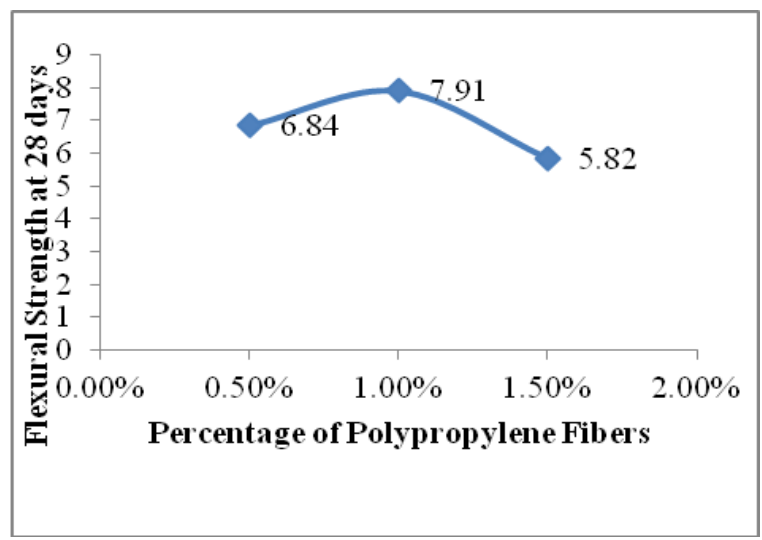

Fig.9.Flexural Strength of Polypropylene Fibers

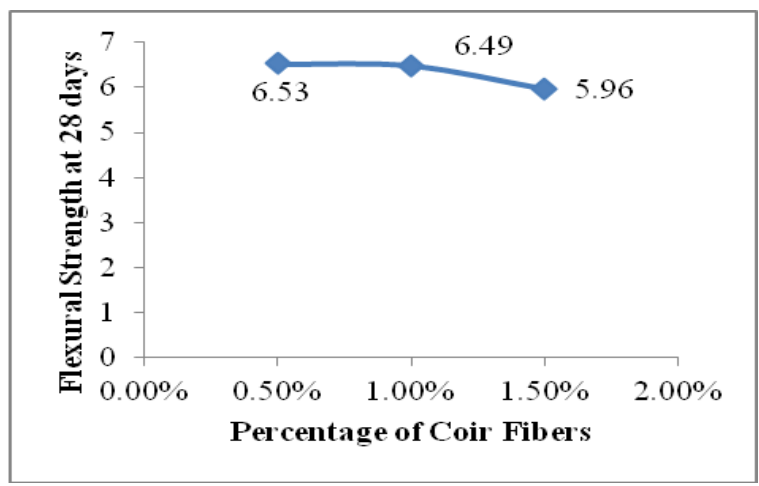

Fig.10.Flexural Strength of Coir Fibers

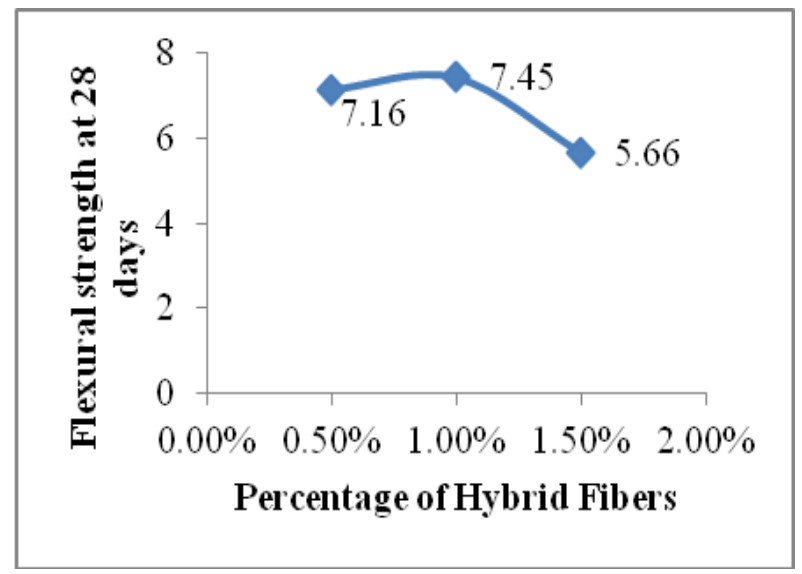

Fig.11.Flexural Strength of Hybrid Fibers

From Figures 3, 6 and 9 it is clear that an optimum value of all strength is found in $1 \%$ of polypropylene fiber fraction. Hence from these results it can be concluded that in polypropylene fiber a maximum strength in gain has been arrived when fiber fraction of $1 \%$ is added to the mix.

From Figures 4, 7 and 10 it is very clear that all the strengths - compressive, flexural and split get an optimum value of 39.45Mpa, 4.15MPa, 6.53MPa when $0.5 \%$ of Coir fiber is added to the GPC specimens. It can be illustrated with results that addition of more fibers in mix could be inversely related to the strength of the specimens.

From the figures 5, 8, and 11 the optimum percentage of hybrid fiber fraction of all the strengths is found in $1 \%$ of $\mathrm{HF}$ with the test results of $39.60 \mathrm{MPa}, 4.67 \mathrm{MPa}$, and 7.45MPa. Increasing percentage of hybrid fiber fraction decreases the strength of the results.[13].

Thus from the test results it is seen that the fibers such as Polypropylene, Coir Fiber and Hybrid Fiber when added to the GPC, increased the strength to an optimum mix of fiber fraction.[14]. Beyond the optimum mix fraction of fibers, the test results get reduced. PF is purely inorganic, while CF is organic and in case of HF which is a combination of PF and CF i.e., organic and inorganic properties.[15]. This study also focused on the achievements of strength in combination of both organic and inorganic constituents under a single roof. In test results, all the three fibers gave the optimum fraction composition at different percentages; in $\mathrm{PF}$ it was found that $1.0 \%$ gave ultimate strength results; in case of CF $0.5 \%$ produce ultimate results and in HF $1.0 \%$ achieve maximum results. It was summarized in table.VII..

Table-VII: Details of Optimum Fiber Fraction Percentage

\begin{tabular}{|l|l|l|}
\hline \multicolumn{3}{|c|}{ Optimum Fiber fraction } \\
\hline Polypropylene fiber & Coir Fiber & $\begin{array}{l}\text { Hybrid } \\
\text { Fiber }\end{array}$ \\
\hline $1.0 \%$ & $0.5 \%$ & $1.0 \%$ \\
\hline
\end{tabular}

\section{CONCLUSION}

- Comparison with all fractions of fibers, optimum Percentage of mechanical strength was achieved in GPC when $1 \%$ of polypropylene fibers was added into the GPC specimens.

- Maximum strength properties were achieved when 0.5\% of coir fibers were added in to GPC specimens.

- $\quad$ Addition of $(0.5 \% \mathrm{PF}+0.5 \% \mathrm{CF})$ of hybrid fibers produce maximum strength in GPC mixed with Quarry Rock Dust and Fly ash.

- $1 \%$ of polypropylene fibers gave better results comparative with all fractions of fibers in all the strengths - Compressive, Split Tensile and Flexural Strength.

\section{REFERENCES}

1. Hardjito, D, Wallah, SE, Sumajouw, DMJ \& Rangan, BV (2005).'Introducing fly ash-based geopolymer concrete, Manufacture and Engineering Properties," $30^{\text {th }}$ Conference on our world in Concrete \& Structures, Singapore: 1-9.

2. Joseph Davidovits (2015),"Geopolymer chemistry and application":1-37.

3. Joseph Davidovits (2013), “Geopolymer Cemen”t A Review: 1-11.

4. Jonathan Tailby, Kenneth, JD \& Mackenzie (2010), "Structure and mechanical properties of alumino silicate geopolymer composites with portland cement and its constituent minerals" Cement and Concrete Research, vol. 40, no. 05: 787-794.

5. Manimaran, E \&Mohan kumar, G (2017). "Influence of sodium hydroxide concentration on the strength of fly ash based GPC" International Journal of Engineering Sciences \& Research Technology, vol. 6, no. 1: 85-89.

6. Sreevidya, V, Anuradha, R, Dinakar, D \& Venkatasubramani, R (2012), "Acid Resistance of flyash based Geopolymer mortar under ambient curing and heat curin" International Journal of Engineering Science and Technology, vol. 4, no. 02:681-68.

7. Ilangovan, R, Mahendran, N \& Nagamani, K (2008), "Strength and durability properties of concrete containing quarry rock dust as fine aggregate", ARPN Journal of Engineering and Applied Sciences, vol. 3, no. 5: 20-26.

8. Kolli Ramujee (2013), "Strength properties of polypropylene fiber reinforced concrete', International Journal of Innovative Research in Science, Engineering \& Technology, vol. 2, no. 8: 3409-3413.

\section{Published By:}

Blue Eyes Intelligence Engineering

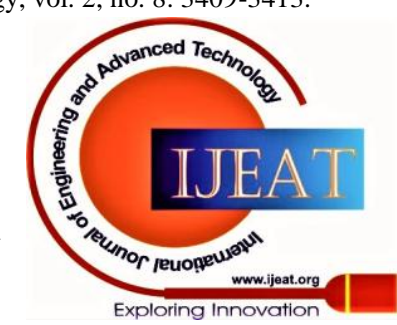


9. Patil, SS \& Patil, AA (2015), "Properties of polypropylene fiber reinforced geopolymer concret", International Journal of Current Engineering and Technology', vol. 5, no. 4: 2909-2912.

10. Ravindra, N, Thakur \& Somnath Ghosh (2009), "Effect of mix composition on compressive strength and microstructure of flyash based geopolymer composites", ARPN Journal of Engineering and Applied Sciences, vol. 4,no. 4:68-74.

11. Mohamed Aquib Javeed, Veerendra Kumar, M \& Narendra, $\mathrm{H}$ (2015),"Studies on mix design of sustainable geo-polymer concrete", International Journal of innovative Research in Engineering \& Management (IJIREM), vol. 2, no. 4:9-14.

12. Sachinpaul \& Shibilumar, A (2014),"Study on properties of hybrid fibre reinforced GPC", Transactions on Engineering and Sciences', vol. 2, no. 10: 36-39.

13. Sachinpaul \& Shibilumar, A (2014),"Study on properties of hybrid fibre reinforced GPC", Transactions on Engineering and Sciences, vol. 2, no. 10: 36-39.

14. Sivaraja, M Kandasamy, S \& Thirumurugan, A (2010), "Mechanical properties of fibrous concrete with waste rural materials", Journal of Scientific \& Industrial Research, vol. 69: 308-312.

15. Sangameshupasi, Sunilkumar, H, Manjunatha, H \& Prakash, KB (2014),"An investigation on strength characteristics", International Journal of Engineering Research,vol.2,no.5:57-67

\section{AUTHORS PROFILE}

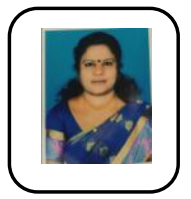

Dr. S.Kavipriya working as Associate Professor and Head of the Department of Civil Engineering in Kongunadu College of Engineering and Technology, Thottiam. I have completed my PG in NIT, Trichy and doctorate in Anna University, Chennai. I am having around 16 years of teaching experience.

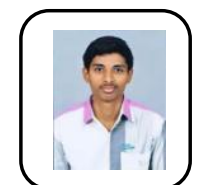

Mr. S.Gowtham working as Assistant Professor in Kongunadu College of Engineering and Technology, Thottiam.I have completed my PG in Karunya University, Coimbatore. I am having around 3 years of teaching experience.

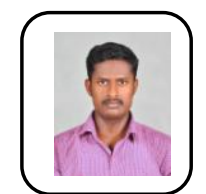

Mr. S.Kannan working as Assistant Professor in Kongunadu College of Engineering and Technology, Thottiam. I am having around 3 years of teaching experience.

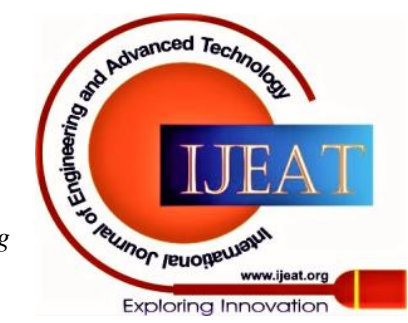

